\title{
Pengelolaan Fraktur Dentoalveolar pada Anak-Anak dengan Cap Splint Akrilik
}

\author{
Dedy Sigit Nurcahyo*, Maria Gorreti**, dan Poerwati Soeji*** \\ ${ }^{*}$ Residen Bedah Mulut \& Maksilofasial, Fakultas Kedokteran Gigi, Universitas Gadjah Mada, Yogyakarta, Indonesia \\ **Bagian Bedah Mulut \& Maksilofasial Rumah Sakit Umum Pemerintahan Dr. Sarjito, Yogyakarta, Indonesia \\ ***Bagian Bedah Mulut \& Maksilofasial, Fakultas Kedokteran Gigi, Universitas Gadjah Mada, Yogyakarta, Indonesia \\ *JI Denta No 1 Sekip Utara, Yogyakarta, Indonesia; e-mail: dedysigitn@yahoo.com
}

\begin{abstract}
ABSTRAK
Tujuan perawatan fraktur pada anak-anak pada dasarnya sama dengan orang dewasa, tetapi dengan managemen yang berbeda, dimana perkembangan rahang dan gigi geligi menjadi pertimbangan utama dalam pemilihan metoda perawatan. Melaporkan dua kasus fraktur dentoalveolar pada anak dibawah 5 tahun yang dirawat dengan menggunakan cap splint akrilik dengan sirkum mandibular wiring dengan anastesi umum. Dua orang anak, umur 1 tahun dan 3 tahun datang dengan rujukan ke unit gawat darurat RSS dengan diagnosa fraktur dentoalveolar, pada kedua kasus dilakukan perawatan menggunakan caps splint dengan fiksasi menggunakan sirkum mandibular wiring dengan anastesi umum. Setelah 3 minggu cap splint akrilik dan sirkum mandibular wiring di lepas dengan sedasi. Pada daerah fraktur tidak di jumpai kegoyahan. Kontrol minggu ke 6, gigi stabil tanpa kegoyahan, oklusi normal, tidak terdapat infeksi. Cap splint akrilik dengan sirkum mandibular wiring adalah salah satu metode pilihan yang simpel, efektif dengan invasif minimal yang dapat digunakan sebagai pilihan untuk perawatan kasus fraktur dentoalveolar pada anak.
\end{abstract}

Maj Ked Gi Ind. Desember 2015; 1(2): 216 - 222

Kata kunci: fraktur dentoalveolar pada anak-anak, cap splint akrilik

\begin{abstract}
Management of Dentoalveolar Fractures in Children Using Acrylic Cap Splint. The purpose of fracture treatment in children is basically the same as that in adults with different management, while the choice of treatment method mainly relies on the development of jaws and teeth. It reports two cases of dentoalveolar fractures in children under 5 years old who were treated using acrylic cap splint with circum-mandibular wiring under general anesthetic. Two children, aged 1 year and 3 years old were referred to the emergency department of Dr. Sardjito Hospital with the diagnosis of dentoalveolar fractures. Both cases were treated using cap splint with circum-mandibular wiring-based fixation under general anesthetic. After 3 weeks, the acrylic cap splint and the circum-mandibular wiring were released under sedation. No loose teeth were found in the fracture area. In the following 6 weeks, the teeth were stable with normal occlusion and no infection found. Acrylic cap splint with circum-mandibular wiring is a simple, effective and minimally invasive method for dentoalveolar treatment in children.
\end{abstract}

Maj Ked Gi Ind. Desember 2015; 1(2): 216 - 222

Keywords: dentoalveolar, fractures in children, acrylic cap splint

\section{PENDAHULUAN}

Trauma dentoalveolar adalah trauma yang mengenai gigi dan tulang alveolar pada maksila atau mandibula dan jaringan pendukung gigi. Trauma dentoaveolar $60 \%$ terjadi pada anak khususnya di bawah umur 5 tahun tetapi jarang mendapat penanganan di rumah sakit. ${ }^{1}$ Kejadian trauma pada anak laki-laki dua kali lebih sering dibandingkan anak perempuan, hal ini berkaitan dengan aktivitas fisik yang lebih tinggi pada anak laki-laki. Anak-anak dengan kebutuhan khusus lebih rentan terhadap terjadinya trauma, misalnya pada anak dengan keterbelakangan mental, dan epilepsy. ${ }^{3}$

Trauma dentoalveolar dapat menyebabkan fraktur, pergeseran dan hilangnya gigi depan yang mengakibatkan perubahan fungsi, estetis, gangguan berbicara, dan efek psikologis yang dapat mengurangi kualitas hidup. ${ }^{3}$ Tanda-tanda klinis dari fraktur dentoalveolar adalah kegoyahan dan pergeseran pada beberapa gigi dalam satu segmen, luka pada gingiva serta pembengkakan pada dagu. ${ }^{1,4}$

Penyebab utama fraktur dentoalveolar adalah jatuh, kecelakaan lalu lintas, dan kekerasan pada anak. Faktor-faktor yang menjadi pertimbangan dalam melakukan tindakan dalam penanganan trauma dentoalveolar diantaranya: (1) Umur dan kooperatif tidaknya anak; (2) Durasi antara trauma dan perawatan; (3) Lokasi dan perluasan; (4) Injury terjadi pada gigi permanen atau gigi susu; (5) Perkembangan akar gigi; (6) Ada tidaknya fraktur 
pada pendukung tulang; (7) Kesehatan jaringan periodontal dan gigi yang tersisa. ${ }^{5}$

Perbedaan pola fraktur pada anak-anak dibandingkan dengan orang dewasa adalah adanya pertumbuhan dan perkembangan dari tulang wajah, perkembangan sinus paranasal, dan struktur tulang pada anak-anak yang elastik, ${ }^{6}$ dimana elastisitas dari tulang mandibula dan gigi yang belum erupsi dapat sebagai perekat, penahan bersama, terhadap fraktur. ${ }^{5}$ Anak-anak mempunyai potensi osteogenik yang besar dan penyembuhan yang lebih cepat dari pada orang dewasa. Oleh karena itu, reduksi harus dilakukan dengan cepat dan waktu imobilisasi harus lebih pendek yaitu 2 minggu. Waktu ini lebih pendek daripada waktu imobilisasi pada orang dewasa yaitu 4-6 minggu. ${ }^{8}$ Fiksasi pada anak-anak biasanya dilakukan selama 3 minggu. Fraktur greenstick cenderung terjadi pada anak-anak dan memerlukan observasi atau tindakan fiksasi yang minimal. ${ }^{7}$

Tujuan perawatan fraktur pada anak-anak sama dengan orang dewasa tetapi dengan manajemen yang berbeda, dimana perkembangan rahang dan pertumbuhan gigi geligi menjadi pertimbangan utama dalam pemilihan metoda perawatan. ${ }^{8}$ Manajemen fraktur pada masa gigi susu dan bercampur memiliki beberapa kesulitan. Pertama, adanya gigi permanen yang belum erupsi sampai umur 6 tahun atau lebih sehingga ORIF (Open reduction internal fixation) dapat menyebabkan trauma pada benih gigi dan hanya dapat dilakukan secara monokortikal, ${ }^{6}$ yaitu pada inferior border mandibula. ${ }^{1}$ Kedua, kesulitan untuk melakukan IMF (Intermaxillary fixation) pada gigi yang belum erupsi atau belum erupsi sempurna. ${ }^{6}$

Perawatan fraktur dentoalveolar dilakukan dengan mereduksi atau mengembalikan segmen fraktur pada posisi sebenarnya dan dilakukan fiksasi sampai terjadi penyembuhan tulang. Reduksi tulang dapat dilakukan secara bertahap dengan guiding elastic, menggunakan teknik ortodontik ${ }^{1}$ dan dengan menekan segmen tulang atau gigi secara digital pada tulang alveolus dan gigi. ${ }^{9}$ Fiksasi dapat dilakukan dengan dental wiring, arch bar, resin komposit. Teknik sirkum mandibular wiring adalah metode dengan invasif minimal, dengan stabilisasi yang baik dibandingkan metoda ORIF. ${ }^{6}$ Tujuan dari studi kasus ini adalah untuk melaporkan dua kasus fraktur dentoalveolar pada anak di bawah 5 tahun yang dirawat dengan menggunakan cap splint akrilik dengan sirkum mandibular wiring.

\section{METODE}

\section{Kasus 1}

Seorang anak laki-laki umur 1 tahun datang ke Unit Gawat Darurat RSS atas rujukan dari sebuah rumah sakit swasta dengan keluhan terdapat perdarahan pada rongga mulut dan kegoyahan pada gigi depan bagian bawah setelah terjatuh dari tangga rumah saat bermain. Pada anamnesa pasien tidak mengalami pingsan, muntah serta tidak memiliki riwayat penyakit sistemik.

Pada pemeriksaan klinis, keadaan umum pasien, compos mentis. Tensi $95 / 65 \mathrm{mmHg}$, pernafasan $28 x /$ menit, nadi $124 x /$ menit, suhu $36^{\circ} \mathrm{C}$, VAS:1. Pada pemeriksaan ekstra oral tidak ditemukan adanya kelainan. Intra oral terdapat malposisi gigi 71, 72, 81, 82 ke arah labial dengan luksasi derajat 2, perdarahan sudah berhenti, tampak hematom di gingiva lingual regio $71,72,81$, 82 (Gambar 1). Sebelum dilakukan tindakan pasien mengisi dan menandatangani informed consent dan setuju dilakukan tindakan dan setuju kasusnya dipublikasikan.

Pemeriksan rontgen PA (Postero anterior) menunjukkan terdapat garis fraktur horizontal pada alveolar regio $71,72,81,82$ serta tidak dijumpai kelainan pada tulang maksila dan mandibula. Terdapat malposisi gigi $71,72,81,82$ serta gambaran gap pada apeks gigi $71,72,81$, 82. Hasil laboratorium pemeriksaan darah dalam batas normal. Berdasarkan pemeriksaan klinis dan radiologis mengarah pada diagnosa fraktur dentoalveolar tertutup tanpa komplikasi pada regio 71, 72, 81, 82 (Gambar 3).

Rencana perawatan adalah reduksi dan fiksasi dengan cap splint akrilik menggunakan metode sirkum mandibular wiring dengan general anestesi. Pertama, rongga mulut pasien dicetak untuk mendapatkan model kerja, kemudian hasil cetakan tersebut dibuat cap splint akrilik dengan 
posisi gigi disesuaikan dengan posisi normal (Gambar 4). Di ruang operasi setelah pasien dianestesi umum, dilakukan tindakan aseptic pada daerah operasi ekstra dan intra oral. Gigi rahang atas dan bawah dioklusikan untuk mendapatkan oklusi sentrik. Selanjutnya segmen fraktur direduksi secara manual dengan penekanan tangan sampai didapat oklusi normal, dilanjutkan dengan pemasangan cap splint akrilik. Cap splint akrilik difiksasi pada mandibula menggunakan 2 buah ikatan kawat dengan metode sirkum mandibular wiring yang diinsersikan dengan Awl pada regio parasimfisis dekstra dan sinistra (Gambar 5). Medikasi menggunakan Ampisilin 125 mg/6 jam,

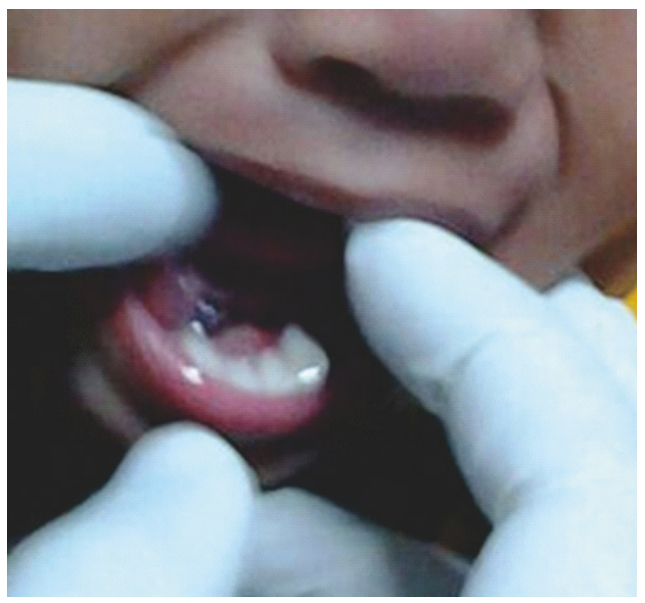

Gambar 1. Keadaan intra oral pasien terdapat kegoyahan pada gigi $71,72,81,82$.

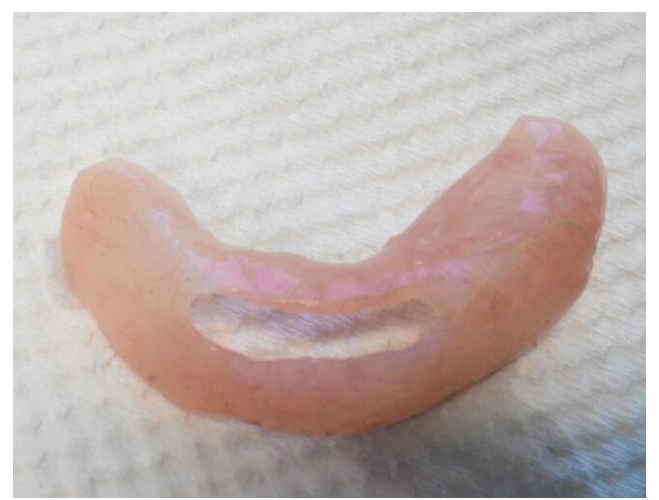

Gambar 3. Splint Akrilik yang akan digunakan untuk fiksasi fraktur dentoalveolar. paracetamol $125 \mathrm{mg} / 8$ jam, dexamethasone 1,25 $\mathrm{mg} / 8$ jam, dan setelah 2 hari pasien dipulangkan. Pada saat kontrol minggu pertama dan kedua, tidak terdapat peradangan, dan cap splint akrilik terpasang dengan baik, serta banyak terdapat food debris. Setelah 3 minggu cap splint akrilik dan sirkum mandibular wiring dilepas dengan sedasi. Pada gigi 71, 72, 81, 82 sudah tidak dijumpai kegoyahan gigi, dengan oklusi normal. Kontrol minggu ke 6, gigi telah stabil tanpa kegoyahan, oklusi normal, dan tidak terdapat infeksi (Gambar 6). Gambaran radiologi menunjukkan masih terdapat sedikit diskontinuitas pada parasimfisis mandibula kiri (Gambar 7).

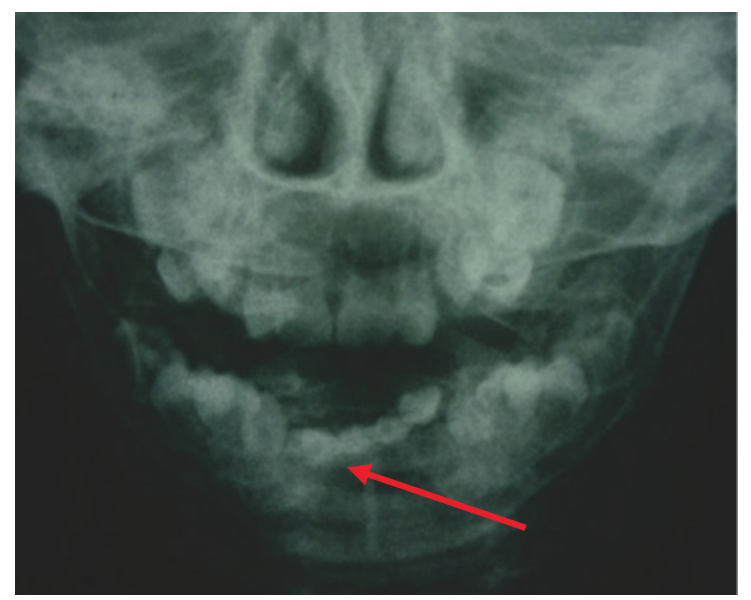

Gambar 2. Rontgen PA, menunjukkan terdapat garis fraktur horizontal pada alveolar regio $71,72,81,82$

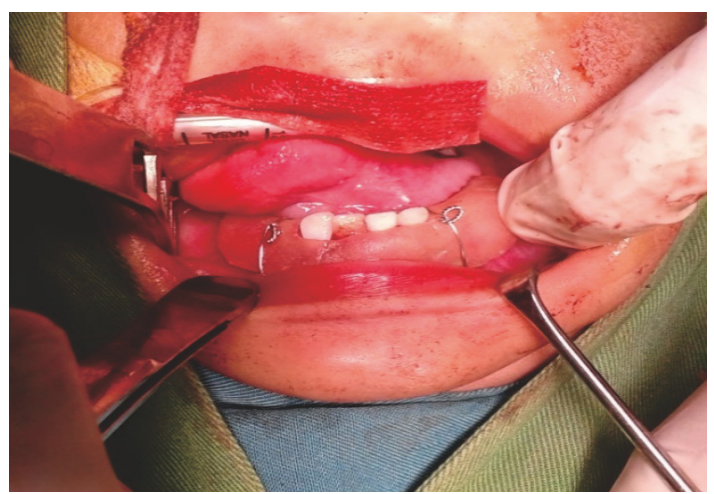

Gambar 4. Fiksasi dengan metode sirkum mandibular 


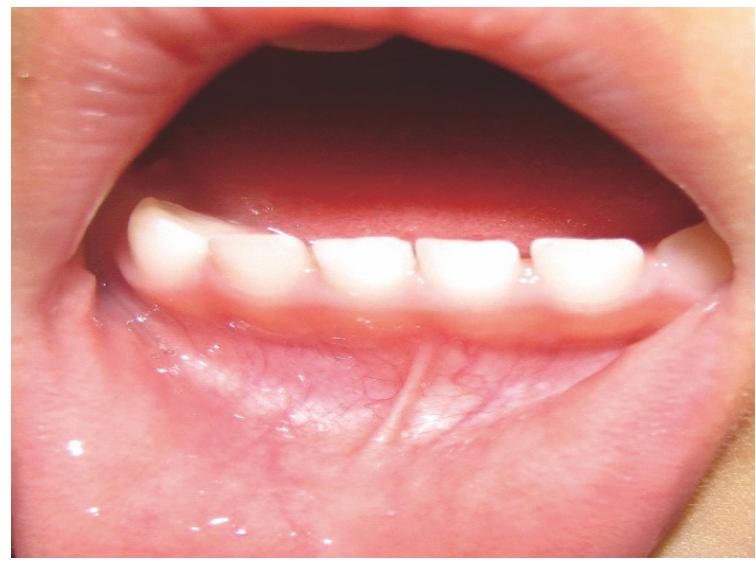

Gambar 5. Keadaan pasien setelah 6 minggu, gigi telah stabil tanpa kegoyahan, oklusi normal, dan tidak terdapat infeksi

\section{Kasus 2}

Seorang anak perempuan umur 3 tahun dibawa ke unit gawat darurat RSS atas rujukan dari sebuah rumah sakit swasta dengan keluhan terdapat perdarahan pada rongga mulut dan kegoyahan pada gigi depan bagian bawah setelah terjatuh dari tangga rumah saat bermain. Pada anamnesis pasien tidak mengalami pingsan, muntah serta tidak terdapat riwayat penyakit sistemik (Gambar 8). Sebelum dilakukan tindakan pasien mengisi dan menandatangani informed consent dan setuju dilakukan tindakan dan bersedia kasusnya dipublikasikan.

Pada pemeriksaan klinis, keadaan umum pasien compos mentis. Tensi 100/65 mmHg pernafasan $27 \mathrm{x} /$ menit, nadi $130 \mathrm{x} /$ menit, suhu $36^{\circ} \mathrm{C}$ VAS:2. Ekstra Oral terdapat hematom pada dagu kiri. Intra oral terdapat gap pada gigi 71, 72 dengan gigi sekitar dengan luksasi derajat 2. Pada rahang atas terdapat fraktur Ellis kelas VII disertai intrusi dan fraktur mahkota sampai batas leher gigi, pada gigi $51,52,61,62$, terdapat vulnus laceratum pada regio $51,51,61,62$.

Pada pemeriksan rontgen AP terdapat garis fraktur obliq pada tulang alveolar regio $71,72$. Tidak dijumpai kelainan pada tulang maksila dan mandibular. Pada Hasil Laboratorium darah dalam batas normal.

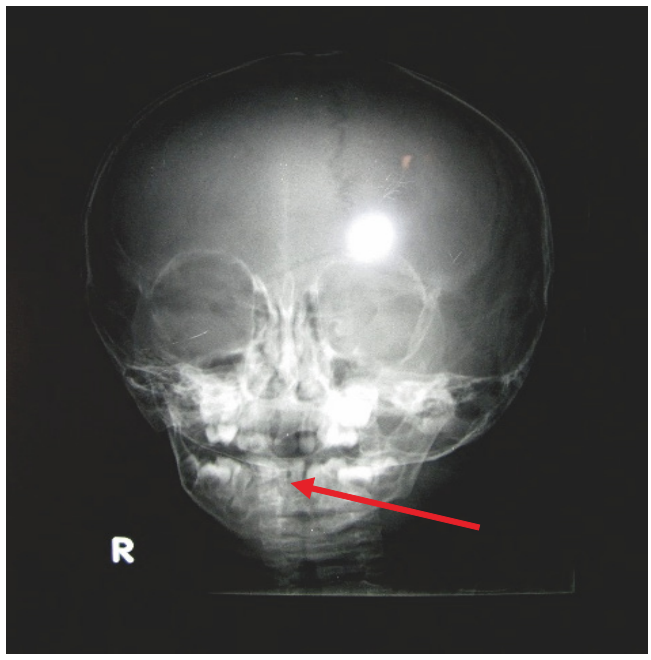

Gambar 6. OPG pasien setelah 6 minggu, menunjukkan masih terdapat sedikit diskontinuitas pada parasimfisis mandibula kiri.

Berdasarkan hasil pemeriksaan klinis dan radiologis mengarah pada diagnosa fraktur dentoalveolar regio 71, 72 (Gambar 10). Rencana perawatan adalah reduksi dan fiksasi menggunakan cap splint akrilik dengan metoda sirkum mandibular wiring dengan anastesi umum. Pasien dicetak untuk membuat model kerja sebagai dasar pembuatan cap splint akrilik dimana gigi diposisikan pada posisi normal (Gambar 11). Di ruang operasi setelah pasien dianestesi umum, selanjutnya dilakukan tindakan aseptik pada daerah operasi ekstra dan intra oral. Dilakukan pencabutan gigi anterior rahang atas $(51,52,61$, 62). Segmen fraktur pada gigi 71 dan 72 direduksi dengan penekanan tangan sampai didapat posisi normal, kemudian cap splint akrilik dipasang. Cap splint akrilik difiksasi pada mandibular dengan menggunakan 2 buah ikatan kawat dengan metoda sirkum mandibular wiring pada regio parasimfisis dekstra dan sinistra, yang diinsersikan dengan menggunakan Awl (Gambar 12). Medikasi dengan pemberian ampisilin $150 \mathrm{mg} / 6$ jam, paracetamol $500 \mathrm{mg} / 8 \mathrm{jam}$, dexamethasone 1,25 mg/8 jam, dan setelah 2 hari dirawat, pasien dipulangkan. Pada saat kontrol minggu pertama dan kedua tidak terdapat peradangan, dan cap splint akrilik masih baik terpasang, dengan banyak terdapat food debris. Setelah 3 minggu cap splint akrilik dan sirkum mandibular wiring dilepas dengan 
sedasi. Pada segmen fraktur sudah tidak dijumpai kegoyahan dengan oklusi normal. Kontrol minggu ke 6, gigi 71, 72 stabil tanpa kegoyahan, oklusi normal, tidak terdapat infeksi (Gambar 13).

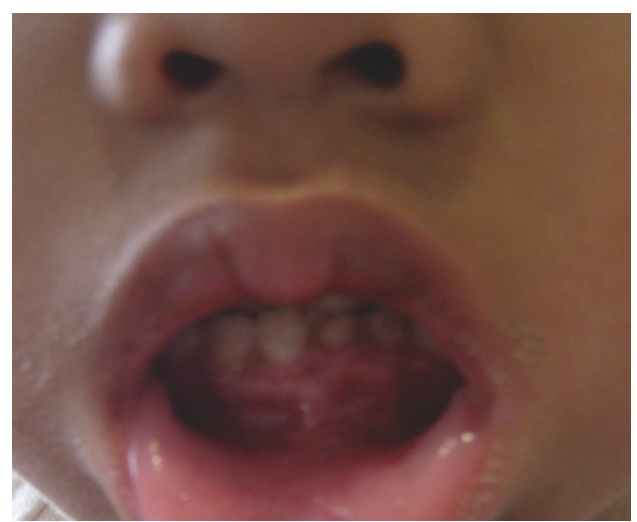

Gambar 7. Keadaan intra oral pasien sebelum dilakukan fiksasi

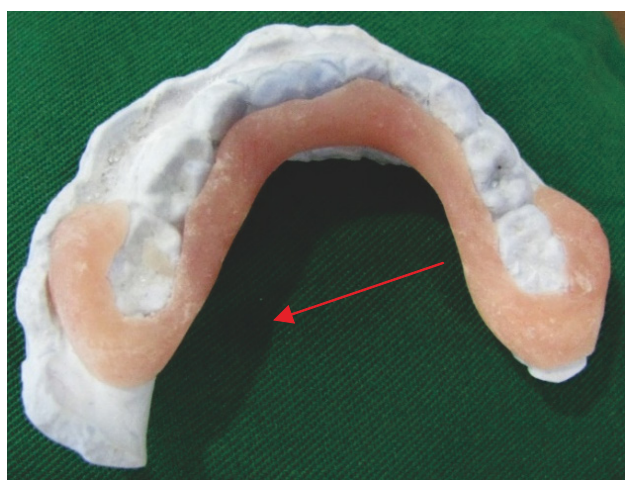

Gambar 9. Splint Akrilik yang digunakan untuk fiksasi fraktur dentoalveolar.

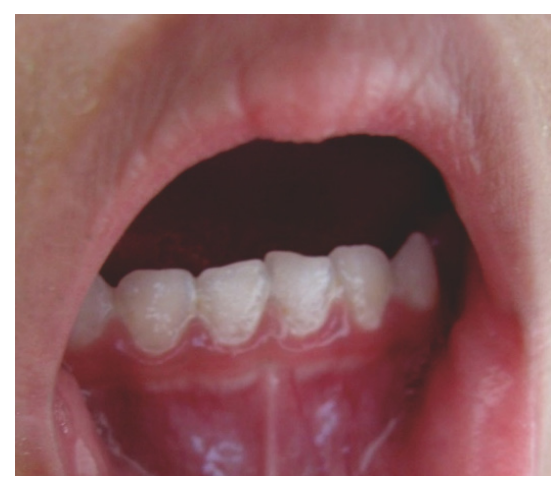

Gambar 11. Keadaan intra oral pasien setelah 6 minggu gigi 71, 72 stabil tanpa kegoyahan, oklusi normal, tidak terdapat infeksi.
Pada gambaran radiologis tampak gambaran os mandibula yang tervisualisasi utuh dan tak tampak lesi titik maupun sklerotik pada sistema tulang yang tervisualisasi (Gambar 14).

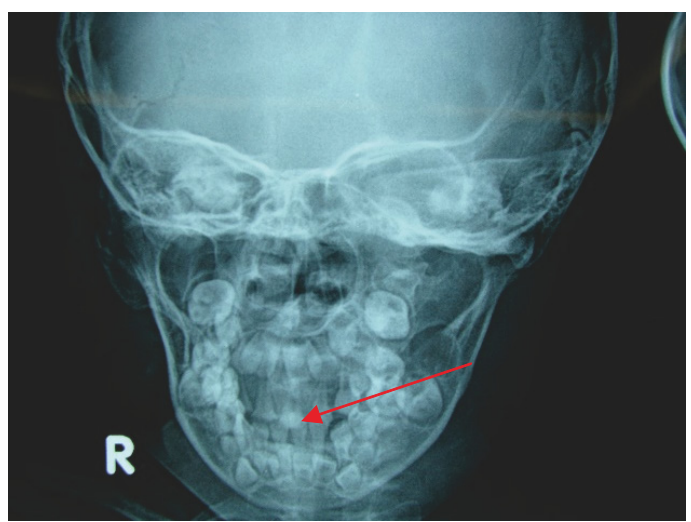

Gambar 8. Rontgen PA, terdapat garis fraktur obliq pada tulang alveolar regio 71,72 . Tidak dijumpai kelainan pada tulang maksila dan mandibula.

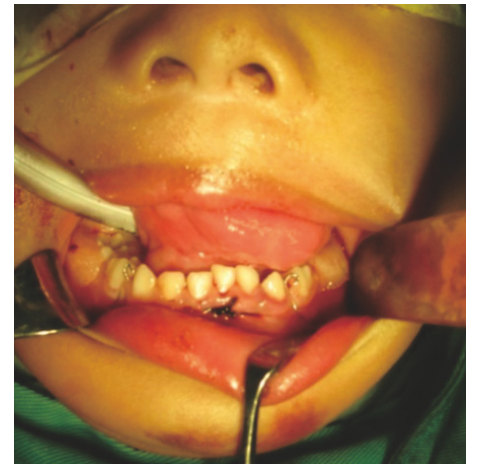

Gambar 10. Fiksasi splint akrilik dengan metode sirkum mandibular

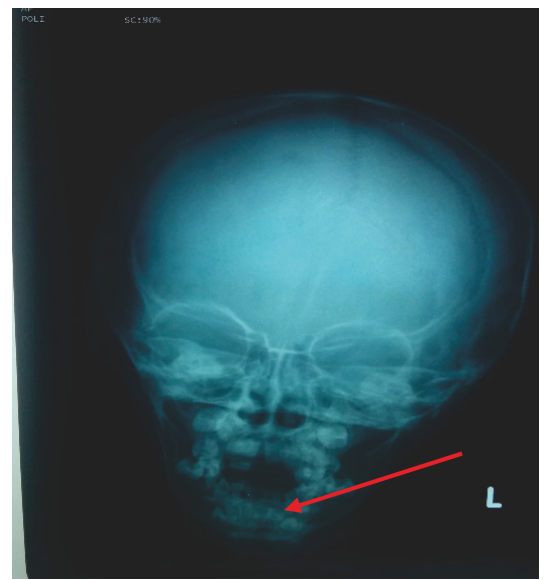

Gambar 12. OPG pasien setelah 6 minggu, tampak gambaran os mandibula yang tervisualisasi utuh dan tak tampak lesi titik maupun sklerotik pada sistema tulang yang tervisualisasi 


\section{PEMBAHASAN}

Fraktur dentoalveolar didefinisikan sebagai kerusakan atau putusnya kontinuitas jaringan keras pada stuktur gigi dan tulang alveolar yang disebabkan trauma, ${ }^{11}$ atau fraktur yang meliputi avulsi, subluksasi, atau fraktur gigi yang berkaitan dengan fraktur tulang alveolar. Fraktur dentoalveolar dapat terjadi tanpa atau disertai dengan fraktur bagian tubuh lainnya, biasanya terjadi akibat kecelakaan ringan seperti jatuh, terbentur saat bermain, berolahraga atau iatrogenik. ${ }^{10}$

Tanda-tanda klinis fraktur dentoalveolar diantaranya adalah adanya kegoyahan dan pergeseran beberapa gigi dalam satu segmen, laserasi pada gingiva dan vermilion bibir, luka pada gingiva dan hematom di atasnya, nyeri tekan pada daerah garis fraktur serta adanya pembengkakan atau luka pada dagu. Pemeriksaan klinis yang teliti dan pemeriksaan radiografi diperlukan untuk menegakkan diagnosis. ${ }^{4}$

Ellis melaporkan insidensi fraktur sekitar 4,2\%, hal itu berarti apabila terdapat 100 orang, maka 5 diantaranya mengalami fraktur dentoalveolar. ${ }^{11}$ Anak laki-laki lebih beresiko mengalami fraktur 2 sampai 3 kali lebih banyak dari pada anak perempuan. ${ }^{1}$ Perawatan fraktur dentoalveolar meliputi reduksi segmen fraktur dan fiksasi sampai terjadi penyembuhan tulang. Reduksi segmen fraktur dapat dilakukan dengan reduksi tertutup atau reduksi terbuka. Reduksi tertutup segmen fraktur dilakukan dengan penekanan secara digital sampai pada posisi anatomisnya. Reduksi terbuka dilakukan bila terdapat serpihan tulang atau tepi segmen yang mempersulit reposisi. Pada kedua kasus diatas dilakukan reduksi tertutup karena tidak terdapat pergeseran segmen fraktur yang jauh dan tidak terdapat fragmen tulang atau jaringan granulasi yang menghalagi reposisi. Reduksi dilakukan secara sederhana dengan penekanan pada segmen fraktur sehingga diperoleh posisi anatomis.

Terdapat beberapa metode untuk memfiksasi segmen tulang diantaranya interdental wiring, arch bar, dan splint akrilik. ${ }^{1}$ Splinting tidak diperlukan pada fraktur dentoalveolar anak yang tidak menimbulkan perpindahan segmen tulang atau gigi karena proses penyembuhan tulang pada anak yang cepat. Perawatan cukup dengan diet lunak selama 2 minggu dengan pemeriksaan periodontal yang rutin. Splinting beberapa gigi pada bagian mesial dan distal segmen fraktur diperlukan jika terdapat perpindahan segmen fraktur yang minimal. ${ }^{12}$

Pada kasus ini digunakan cap splint akrilik untuk fiksasi segmen fraktur. Metode lain tidak bisa digunakan karena gigi belum semuanya erupsi dan bentuk mahkota gigi decidui yang tidak memungkinkan dilakukan fiksasi menggunakan arch bar. Metode splint dipilih karena mengurangi penggunaan IMF, menghindari ankylosis dan gangguan pertumbuhan, mudah digunakan, atraumatik, tidak merusak gigi dan benih gigi. ${ }^{13} \mathrm{Cap}$ splint akrilik tidak hanya menyediakan dukungan dari gigi sekitar tetapi juga dukungan dari tulang. ${ }^{5}$ Cap splint akrilik difiksasi pada mandibular dengan menggunakan fiksasi sirkum mandibular dengan 2 ikatan yaitu pada regio parasimfisis dekstra dan sinistra, dimana posisi gigi yang di pasang splint dapat terlihat, fiksasi fragmen dilakukan sampai terjadi penyembuhan tulang kurang lebih 3 minggu.

Kawat-kawat untuk fiksasi cap splint diinsersikan mengunakan awl atau dengan metode jarum lurus dengan venflon no.20. Pada teknik menggunakan awl, awl didorong masuk melalui kulit di bawah dagu ke arah kranial menuju ke rongga mulut pada permukaan lingual mandibular. Kawat stainless steel 0,4 mm dipasang pada ujung Awl (Gambar 13A), selanjutnya Awl ditarik ke tepi bawah mandibular dengan mempertahankan posisi awl terletak di dekat tulang (Gambar 13B). Selanjutnya awl dilewatkan melingkari tepi bawah dari mandibula dan ditekan ke atas menuju sulkus bukal (Gambar 13C). Kawat pada ujung Awl dilepas dan Awl ditarik dari jaringan melalui bagian luar luka (Gambar 13D). Ujung-ujung kawat dilewatkan di atas splint akrilik dan kemudian diikat. ${ }^{10}$

Kekurangan pemakaian splint akrilik adalah retensi food debris pada badan dan basis alat, yang sulit dibersihkan sehingga menyebabkan inflamasi gingiva atau mukosa, namun hal ini dapat diatasi dengan melakukan edukasi pada orang tua pasien untuk berperan dalam ikut menjaga kebersihan mulut anak. 


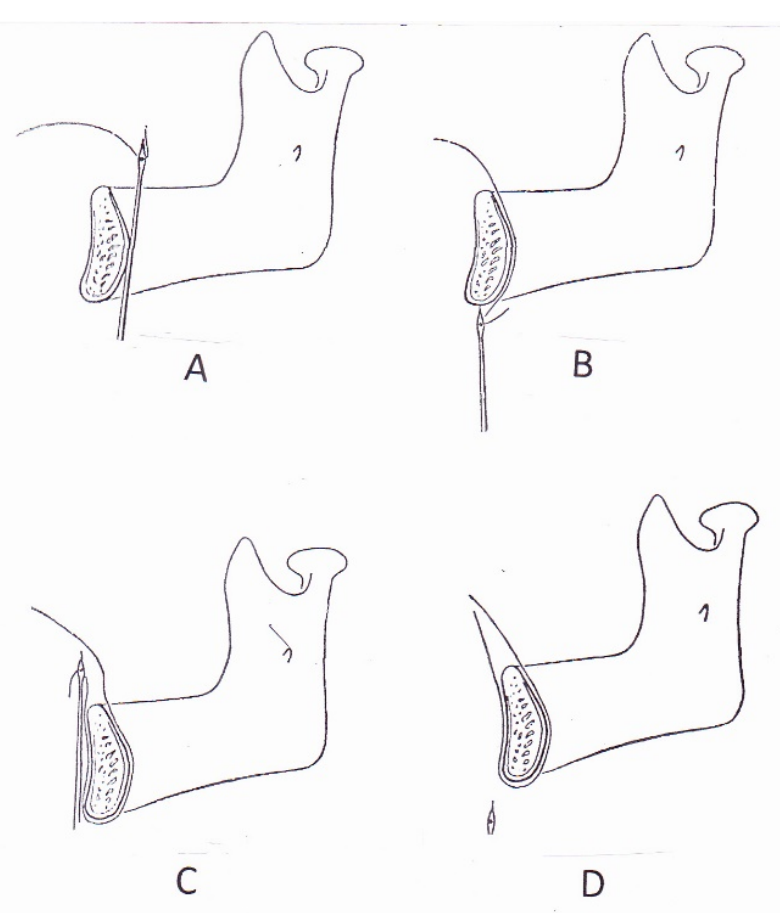

Gambar 13. Penggunaan Awl, ilustrasi teknik penggunaan awl untuk memasang sirkum mandibular wiring. Teknik ini pertama kali di perkenalkan oleh Professor Obwegeser. ${ }^{10}$

\section{KESIMPULAN}

Cap splint akrilik dengan sirkum mandibular wiring adalah salah satu metode pilihan untuk perawatan kasus fraktur dentoalveolar pada anak yang simpel, efektif dengan invasif minimal, yang dapat digunakan sebagai pilihan.

\section{DAFTAR PUSTAKA}

1. Kaban LB. Pediatric oral and maxillofacial surgery. Philadelpia: W.B. Saunders Co; 1990. H.450-451.

2. Singh G, Shadab M, Pal US, Malkunje, Hariram LR, Singh, Nimisha. Pediatric facial injuries: It's management. National Journal of Maxillofacial Surgery. 2011; 2:156.

3. Turkistani J. Recent trends in the management of dentoalveolar traumatic injury to primary and young permanent teeth. Dental traumatology. 2011; 27: 46-54.

4. Syamsudin E, Kasim A. Perawatan fraktur alveolar pada anak-anak dengan menggunakan splint akrilik. Majalah Pabmi. 2014; 2: 117.

5. Vellore KP, Gadipelly S, Duta B, Bhaskar RV, Ram S. Circum mandibular wiring of symphysis fracture in five year old child [Internet]. Hindawi publishing corporation case report in dentistry; 2013 [cited 2014 august10]. Available from Netlibrary: http:// dx.doi.org/10.1155/2013/930789,h.1-4, articleID 930789.

6. Sezer B, Ozveri KB, Akay C, Gunbay T. Splint fixation with circum mandibular wires for pediatric mandibular fracture: two cases reports. EU Dishek Fak Derg. 2010; 31: 113117.

7. Hoog VJ, Nicholous, Horswell, Bruce B. Hard tissue pediatric facial trauma: a review. J Can Dent Assoc. 2006; 72(6): 555.

8. Glazer A, Michael, Zion JBB, Woldenberg C, Yitzhak, Lipa BC. Mandibular fractures in children: analysis of 61 cases and review of the literature. International Journal of Pediatric Otorhinolaryngology. 2011; 75: 62-64.

9. Laskin D, Abubaker O. Decision making in oral and maxillofacial surgery. Chicago: Quintessence Publishing Co, Inc; 2007. H.18.

10. Banks P. Fraktur mandibula (Terj). Ed 1. Jakarta: Hipokrates; 1990. H.78.

11. Selvi AS, Zakyah AD, Fajarwati IS. Makalah fraktur dentoalveolar [Internet]. Fakultas kedokteran gigi universitas padjajaran; 2014 [Cited 2015 Januari 9]. Available from:http:// www.academia.edu.

12. Fonseca RJ. Oral and maxillofacial trauma, Vol.1, $3^{\text {rd }}$ ed. Philadelpia: WB Saunders; 1991. H. 454

13. Ayman $\mathrm{H}$. Management of mandibular fractures in children with a split acrylic splint: a case series. British journal of oral and maxillofacial surgery. 2011; 50: 93-95.

14. Killey HC. Fractures of the middle third of the facial skeleton, $3^{\text {rd }}$ ed. Bristol: John Wright \& Sons. Ltd; 1977. H. 45. 